\title{
Critical education policy and leadership studies (CEPaLS) research interest group (RIG) report
}

DOI:

$10.1177 / 0892020619842761$

\section{Document Version}

Accepted author manuscript

Link to publication record in Manchester Research Explorer

\section{Citation for published version (APA):}

Courtney, S. J., \& McGinity, R. (2019). Critical education policy and leadership studies (CEPaLS) research interest group (RIG) report. Management in Education, 33(3), 140-142. https://doi.org/10.1177/0892020619842761

\section{Published in:}

Management in Education

\section{Citing this paper}

Please note that where the full-text provided on Manchester Research Explorer is the Author Accepted Manuscript or Proof version this may differ from the final Published version. If citing, it is advised that you check and use the publisher's definitive version.

\section{General rights}

Copyright and moral rights for the publications made accessible in the Research Explorer are retained by the authors and/or other copyright owners and it is a condition of accessing publications that users recognise and abide by the legal requirements associated with these rights.

\section{Takedown policy}

If you believe that this document breaches copyright please refer to the University of Manchester's Takedown Procedures [http://man.ac.uk/04Y6Bo] or contact uml.scholarlycommunications@manchester.ac.uk providing relevant details, so we can investigate your claim.

\section{OPEN ACCESS}




\title{
Critical Education Policy and Leadership Studies (CEPaLS) Research Interest Group (RIG) Report
}

\author{
Steven J. Courtney, University of Manchester \\ Ruth McGinity, University College London
}

The purpose of this report is to introduce or reacquaint readers of Management in Education to the scholarship of the BELMAS RIG, Critical Education Policy and Leadership Studies (CEPaLS). We will do that by exemplifying our scholarly activity in the following broad themes: events; research; publications; and networks.

\section{Events}

Members of the BELMAS CEPaLS RIG meet two or three times a year at one of our three centres: UCL and the Universities of Manchester and Nottingham. One of these meetings will take place over two days to allow for deeper collaboration and sustained activity. The events are themed according to our strategic research plan, and so address in turn "privatisation and corporatisation"; "practice and professionalism"; "knowledge production and globalisation"; and "leadership and entrepreneurialism".

Our last meeting was in Manchester from 28-29 June 2018, and focused on the third of these themes over two days. Two keynote speakers presented to the RIG on different aspects of knowledge production and globalisation, bringing to bear their research activities and their new conceptualisations of the field. The first was Prof Roger Dale (University of Bristol), co-founder of Globalisation, Societies and Education, and the second was Dr Stephen Parker (University of Glasgow), Managing Editor of Critical Studies in Education. On day two, Prof Helen Gunter (University of Manchester) led a methodological workshop on "Investigating knowledge production: Identifying and using primary sources".

\section{Research}

CEPaLS members undertake a wide range of research that illuminates power relations and structural inequity in the fields of educational leadership and policy. Recent notable examples include CEPaLS co-convenor, Dr Rob Higham (UCL), whose research into the 'self-improving system' agenda (Greany and Higham, 2018) has been widely reported. Dr Steve Courtney won a British Academy Rising Star Engagement Award in 2017 for his project, "Privatisation in education across Europe: New forms in a changing context". This funding enabled researchers from across Europe to convene and share the implications of their latest analyses (see Courtney 2018). Prof Howard Stevenson has also led important research on trade unions for the teaching profession with fellow University of Nottingham researchers and CEPaLS members, Alison Milner and Emily Winchip. This project was funded by the European Trade Union Committee for Education.

\section{Publications}

CEPaLS members publish widely in highly rated journals, for example, in Journal of Education Policy (Rayner et al., 2018); Educational Management, 
Administration \& Leadership (Gibson and Simon, 2018); Management in Education (Rayner, 2017); British Journal of Sociology of Education (Courtney, 2017); Journal of Educational Administration and History (Courtney, 2018b); and Educational Review (Winchip et al., 2018).

Two CEPaLS books were launched in June 2018 at the University of Manchester (Lim, 2018a). The first was "Educational leadership: Theorising professional practice in neoliberal times", edited by Courtney, McGinity and Gunter (2018) and with contributions from CEPaLS members including Drs Kay Fuller, Linda Hammersley-Fletcher, Stephen Rayner and Prof Pat Thomson. The collection seeks to highlight the crucial role of theory and theorising in making sense of educational leaders' identifications and roles in times of reform. The second, titled "Inside the autonomous school: Making sense of a global educational trend", was written by CEPaLS member Dr Maija Salokangas (Trinity College Dublin), with Prof Mel Ainscow (University of Manchester). The two books were introduced and highly recommended by Profs David James and Terry Wrigley respectively (Lim, 2018b). Other recently published CEPaLS books focus on an intellectual history of school leadership (Gunter, 2016); the politics of public education (Gunter, 2019); and educational leadership and Pierre Bourdieu (Thomson, 2017).

\section{Networks}

CEPaLS at BELMAS is affiliated with a number of national and international networks. The strongest links are those with the University of Manchester research group also known as CEPaLS. The two CEPaLS share an imbricated history, membership and founding convenor in Prof Helen Gunter, as well as mutually reinforcing intellectual projects.

Two networks provide international affiliations and foci. Both have scholars from across Europe and beyond. One of these networks is LE@DS, with a focus on leading democratic schools, and the other is PoPE, or Processes of Privatisation in Europe. These networks continue to generate major collaborations, visits and funding bids.

\section{Plans}

CEPaLS aims to strengthen and expand its research activities both through and beyond the networks listed above. For instance, we aim to have a strong presence at the 2019 BELMAS conference; Courtney and Gunter are leading an international group of contributors in the production of a landmark criticalleadership textbook; and future CEPaLS events are planned to bring in evergreater numbers of new members with exciting projects of their own.

\section{References}

Courtney SJ (2017) Corporatising school leadership through hysteresis. British Journal of Sociology of Education 38(7). Routledge: 1054-1067.

Courtney SJ (2018a) Privatisation in Education Across Europe. Available at: https://privatisationineducation.wordpress.com/.

Courtney SJ (2018b) Privatising educational leadership through technology in the Trumpian era. Journal of Educational Administration and History 50(1). 
Taylor \& Francis: 23-31. DOI: 10.1080/00220620.2017.1395826.

Courtney SJ, McGinity R and Gunter HM (2018) Educational leadership:

Theorising professional practice in neoliberal times. Courtney SJ, McGinity R, and Gunter HM (eds). Abingdon and New York: Routledge.

Gibson MT and Simon S (2018) Losing your head: Are principals attached to their school? Educational Management, Administration and Leadership: 120. DOI: $10.1177 / 1741143218788579$.

Greany T and Higham R (2018) Hierarchy, Markets and Networks: Analysing the 'self-improving school-led system' agenda in England and the implications for schools. London: UCL IoE Press.

Gunter HM (2016) An intellectual history of school leadership practice and research. London and New York: Bloomsbury.

Gunter HM (2019) The Politics of Public Education. Bristol: Policy Press.

Lim MA (2018a) No Title. Available at: https://twitter.com/miguel_a_lim/status/1012387347395174401 (accessed 6 December 2018).

Lim MA (2018b) No Title. Available at: https://twitter.com/miguel_a_lim/status/1012384237947932673 (accessed 6 December 2018).

Rayner SM (2017) Admissions policies and risks to equity and educational inclusion in the context of school reform in England. Management in Education 31(1): 27-32. DOI: 10.1177/0892020616687699.

Rayner SM, Courtney SJ and Gunter HM (2018) Theorising systemic change: learning from the academisation project in England. Journal of Education Policy 33(1). Routledge: 143-162. DOI: 10.1080/02680939.2017.1327084.

Thomson P (2017) Educational leadership and Pierre Bourdieu. Abingdon and New York: Routledge.

Winchip E, Stevenson H and Milner A (2018) Measuring privatisation in education: methodological challenges and possibilities. Educational Review 71(1): 81-100. DOI: 10.1080/00131911.2019.1524197. 